\title{
Manufacturing Export Performance: A Trend Analysis Approach
}

\author{
${ }^{1}$ Nafiu Lukman Abiodun, ${ }^{2}$ George Stanley Kinyata, ${ }^{3}$ Osinusi Kunle Bankole \\ ${ }^{1,2}$ Department of Economics and Statistics, Kabale University, Uganda \\ ${ }^{3}$ Department of Economics, Tai Solarin University of Education, Nigeria \\ ${ }^{1}$ lanafiu@kab.ac.ug
}

Received: June 22, 2021. Revised: November 10, 2021. Accepted: November 24, 2021. Published: December 20, 2021.

\begin{abstract}
The study examined the export performance using a trend analysis approach. A graphical demonstration showing the trend of export performance in Nigeria over time was displayed. It also identifies the major determinants of manufacture exports in Nigeria using ordinary least square approach which shows that an increase in the average tariff rate would lead to a decline in the manufacturing exports and its statistically significant at the 5\% level of significance. Capacity utilization has a negative and insignificant with manufactured exports. Also, there is a positive and significant relationship between exchange rate and trade openness at 1 and $5 \%$ level of significance respectively.
\end{abstract}

Keywords-Manufacturing export, capacity utilization, exchange rate and average tariff rate.

\section{INTRODUCTION}

$\mathrm{I}$ n order to promote economic growth and development, past and present governments in Nigeria since independence in 1960 have been quite consistent, at least in theory, through an expression in annual budgets in pursuance of industrial based policies. Starting from the Import Substitution Industrialization (ISI) policy of the development of export-oriented industries in the 1980s; the momentum has not subsided at the policy of development level [1].

Various policy measures were adopted to ameliorate the economy situation, such as the stabilization measures of 1982 , the restrictive monetary policy and stringent exchange control measure of 1984, all proved abortive. This led to the introduction of the Structural Adjustment Programme (SAP) in 1986 [2]. One of the main reasons for the introduction of SAP was to reduce the high dependence of the economy on crude oil as the major foreign earner, by promoting non-oil exports particularly manufactured goods. But the contribution of the manufacturing sub-sector to the GDP has declined steadily, due to a number of factors, from $8.72 \%$, between $1980-1990$

to $7.62 \%$ between $1990-1995$ and to $6.12 \%$ in 2012 [3], [4].

Despite the implementation of four development plans from 1962 - 1985 as well as rolling plans that come with (SAP) in 1986 through the 1990's to propel economic growth and quicken the achievement of structural transformation and diversification, the industrial sector of the Nigerians economy has not been transformed to reflect the objective of the sector. [5]. It still requires a radical structural transformation from its current role of mere assembly of imported components to an integral industry with the domestic economy as its base and propeller. The restructuring of the base of an economy is essentially meant to boost gross national output: substantially increase in the economy's capacity for export, promotes small scale industrialization, improve technological skills and capacity, increase value added via greater utilization of local raw materials and intermediate goods, attract foreign investment and reduce its independence on foreign technology; when these challenges are overcome, country is said to join the league of industrialized nations [1].

In the last decade there have been sweeping changes in the attitude of policy makers towards manufacturing in Africa. Policy rhetoric now focuses on the need for firms to compete and the role of industrial policy is seen to promote the effectiveness of firms in such competition. Such a policy stands in stark contrary to the long history in Africa of protection of its manufacturing sector by means of tariffs and non-tariff barriers to imports so that domestic industry did not need to compete internationally [6].

Improvements in export performance following trade liberalization have been limited in most African countries. Indeed, as a proportion of gross domestic product (GDP), exports in Africa increased by only 10 per cent following liberalization. In comparison, non-African developing countries saw their exports as a share of GDP increase by 62 per cent. The increase in exports was also smaller than the 
increase in imports, leaving the trade balance in Africa in a worse situation after liberalization [5].

Econometric analysis undertaken to estimate the specific effect of liberalization on exports suggests that, other things being equal, liberalized African countries have export-to-GDP ratios that are $9.5 \%$ higher than those of non-liberalized ones. The effect of trade liberalization on the ratio of exports to GDP in Africa appears to be higher than in other developing countries, where trade liberalization led to a $5 \%$ increase in the ratio of exports to GDP. The difference between this result and the descriptive statistics discussed earlier is due to the fact that the econometric model attempts to attribute causality to different factors determining trade performance. Indeed, weak export momentum and inappropriate domestic policies appear to be the main factors explaining this difference. Africa seems less able to maintain its export market share than its competitors from other developing regions. Out of one percentage point of GDP in exports in a given year, African countries are able to keep 0.78 of a percentage points of GDP the following year, as a result of the lower momentum effect. This is lower than in other developing countries where the ratio is 0.87 , other things being equal.

Moreover, domestic policies, proxies by the changes in the real effective exchange rate (which incorporate currency overvaluations), have the highest negative effect on exports in Africa relative to other developing region [5].

In absolute value terms, exports increased by $12 \%$ per annum on average over the period 1995-2006 in Africa. This increase is slightly larger than that observed for all developing countries over the same period. When the increase in value is disaggregated between volume and price effects, however, it appears that this is mainly due to rising world prices for African exports over the last few years. Indeed, export volumes grew by a yearly average of only $6 \%$ over the period, which is lower than the comparable figures for world and developing-country exports $(6.5 \%$ and $9 \%$, respectively). If export unit prices are considered, however, it appears that African exports have benefited from rising prices to a much higher degree than other regions. This suggests that African exports continue to grow at a lower rate than other regions in volume terms and that it is only the rising prices of fuels, minerals and other primary commodities since 2002 that have maintained African export value growth at a level comparable with other developing regions. The trade structure of African countries did not undergo significant changes in the years following trade liberalization. Most countries in the region remain essentially primary commodity exporters, with only a handful of countries drawing a significant part of their export revenue from manufactured products. In comparative terms, sub-Saharan Africa remains the region with the highest dependence on primary commodity exports. It also appears that export concentration has increased in the years following trade liberalization, strengthening Africa's standing as the region with the highest concentration of exports [7].

The purpose of this research work is to;

i. Determine the trend of export performance in Nigeria over time.

ii. Establish the major determinants of manufactured export performance in Nigeria.

\section{LITERATURE REVIEW}

Ref. [8] studied trends and drivers of India export performance using graphical approach and simple percentages found out that gem and jewelry exports constitute a significant share of the country's aggregate exports and have also performed well internationally thereby making Indian an indispensable in this market. There is also decline in cotton export which uses to be India major export in the past. There is evidence of better performance in India export since introduction of trade liberalization policies.

Ref. [9] examined the impact of liberalization on manufacturing sector performance in developing countries by surveying the literature and using descriptive method found out that evidence from least developed country based indicates that trade liberalization is a necessary but not a sufficient condition for rapid total factor productivity. These countries need to address deficiencies such as shortage of human capital, physical infrastructure and institutions to strengthen the case for trade liberalization.

Ref. [10] examined the effect of trade liberalization on manufacturing sector performance in Nigeria, published in journal of international development using granger causality, VAR and IRF (impulse responsive function) found out that Granger cause trade openness affect capacity utilization of manufacturing sector performance, total domestic demand granger cause manufacturing output while trade openness affects total domestic demand all in one-way causality relationship. Vector autoregressive (VAR) and Impulse response function (IRF) approach shows that the country's manufacturing sector performance growth rate is affected by the past values of the GDP.

Ref. [11] assessed exchange rate policy and export performance in efficiency driven economy uses fixed effects method and panel data model concluded that a weakening of the exchange rate does not necessarily improve export performance. Also export growth seems to be associated with stronger exchange rates. The lag effect of exchange rate movement on export performance is slightly more pronounced, the relationship nevertheless remains statistically insignificant. Ref. [12] investigated exports in manufacturing, exchange rates and external exposure: firm level evidence from Turkey, 
using heterogeneous firm model and regression analysis discovered that a real depreciation of the Turkish lira has a positive impact on exports firms. This positive impact in muted for manufacturing firms operating in sectors that use imported inputs intensively.

Ref. [13] on determinants of textile and apparel export performance in Asian countries concluded that tariff and exchange rate has a negative impact on textile and apparel export performance in Asian developing countries especially after the elimination of the quota system.

Ref. [14] queries if trade policy influences export performance, using empirical data $(67-73,77-83)$ they show that changes in world demand carried greater weight in determining export performance than changes in trade policy. The (Spearman) rank correlation between export orientation and growth is high and significant when world market conditions are favorable, also the correlation is stronger (and significant) for higher - income countries for both sub-periods than for lower-income countries. More recently, Ref. [15] investigated the response of Bangladesh's aggregate merchandise exports to a real exchange rate-based trade liberalization programme during the period 1974-2016. Empirical results suggest that there exists a unique long-run or equilibrium relationship among real quantities of export relative export price and export weighted real effective exchange rate, relative export price (lagged two quarter) and a dummy variable capturing the effects of trade liberalization programme have all emerged as important determinants of an aggregate export supply function for Bangladesh.

\section{RESEARCH DESIGN}

The study employed secondary data, which was collected from Statistical Bulletin of the Central Bank of Nigeria. The data on manufacturing exports, exchange rate, capacity utilization and average tariff rate were extracted from CBN Statistical Bulletin, 2016 edition. These data were analyzed to examine the trend of manufacturing export and the determinant of manufacturing export performance in Nigeria. Model was formulated and analyzed with the use of linear regression method.

The model is specified below:

MEt $=f($ TOPt.EXRt.ATRt. CUt $)$

$M E t=b o+b 1 T O P+b 2 E X R t+b 3 A T R+$

$B 4 C U+U i$

Where

$M E t=$ Manufacture exports at time t

TOPt = Trade openness at time $\mathrm{t}$, measure as sum of export and import divided by Gross Domestic Product, GDP
EXTt $=$ Exchange rate at time $\mathrm{t}$

$A T R t=$ Average tariff rate at time $\mathrm{t}$, calculated as non - oil revenue divided by total imports.

CUt $=$ Manufacture capacity utilization at time $\mathrm{t}$

$U t=$ Stochastic error term at time $\mathrm{t}$

\section{INTERPRETATION OF RESULTS}

From 1970 to 1980 the level of manufactured export was very low accounting for less than 43.5 million on average. This was due to the neglect of the manufacturing sector as a result of the concentration on crude oil explorations which generated over $90 \%$ of government revenue since discovery of crude oil. Other factors that caused this low manufactured export is political instability and frequent change of government.

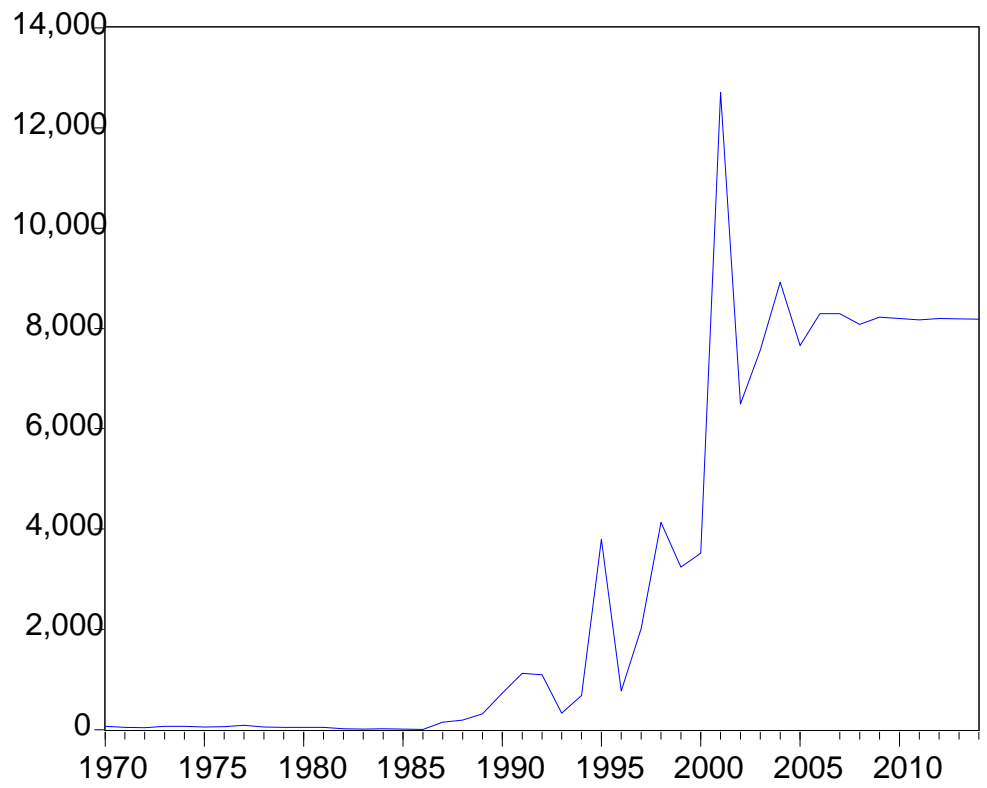

Figure 1. A graph showing manufactured export in Nigeria $(1970-2016)$.

From 1985 - 1990 witness a pick in the manufactured export of the country which was as a result of realization that the country cannot rely so much on the export of crude oil following the sudden fall in the price of crude petroleum in early 1980's. This is because the fall in the price of crude petroleum in the international market brought government activities to a standstill and as a result of the growth in size of government due to the large revenues coming to her during the boom era, between 1995 - 2002 witness a very high increase in the manufacturing export of the country which was due to 
change in government from the military to the civilian government and the quest of the new government to develop infrastructures which is a catalyst to manufacturing sector development, also, government policies that was drive towards encouraging manufacturing sectors. However, there was a sharp decline in the manufactured exports between 2002 2002; this shock was due to the bad state of the power sectors as a result of corruption and lack of maintenance of the national power grade which lead to most manufacturers making use of power generating set to source for energy which subsequently lead to high cost of production and most has to relocated to neighboring countries. From 2002 till 2016, the country witnessed a stable but low manufactured export volume of the country as a result of relatively political stability and favorable government policies that geared toward infrastructural development and diversification of the economy.

Table 1. Ordinary Least Square Results

LMET

ATRT

EXTT

TOPT

$\begin{array}{lrrrr}\text { LMET } & 1.000000 & & & \\ \text { ATRT } & -0.582707 & 1.000000 & & \\ \text { EXTT } & 0.844412 & -0.362620 & 1.000000 & \\ \text { TOPT } & 0.799422 & -0.623156 & 0.635771 & 1.000000 \\ \text { CUT } & -0.340062 & 0.345208 & -0.103972 & -0.502914\end{array}$

\section{$\underline{\mathrm{KEY}}$}

LMET $=$ Log of Manufacture Export at time " $\mathrm{t}$ "

ATRT $=$ Average tariff rate at time " $\mathrm{t}$ "

EXTT $=$ Exchange rate at time " $\mathrm{t}$ "

TOPT $=$ Trade openness at time " $\mathrm{t}$ "

\section{A. Ordinary least square estimate}

The OLS estimates show that an increase in the average tariff rate would lead to a decline in the manufactured exports and it is statistically significant at the $5 \%$ level of significance. This implies that average tariff rate is a significant factor influencing the level of manufactured exports in Nigeria. Also, we found that if the average tariff rate increase by 1 unit, manufactured exports will be reduced by $29.6 \%$. Also, capacity utilization has a negative and insignificant relationship with manufactured exports. Thus, capacity utilization is not a significant factor influencing manufactured exports in Nigeria. Furthermore, we found a positive and significant relationship between exchange rate and trade openness at 1 and $5 \%$ level of significance respectively. In addition, a unit increase in exchange rate and trade openness will lead to an increase of about 2 and $36.2 \%$ respectively. Asides from the magnitude and signs of the parameter estimates, we also consider the adjusted R-square, as well as the $F$ statistic. The adjusted R-square which measures the goodness of fit of the model is $84 \%$. This implies that average tariff rate, exchange rate, trade openness and capacity utilization explain about 84 per cent changes in manufactured exports, while the remaining $16 \%$ are other factors which affect manufactured exports, but were not captured in the model. The $F$ statistic which explains the joint significant of the explanatory variables on the dependent variable is 57.14 and statistically significant at $1 \%$. This implies that average tariff rate, exchange rate, trade openness and capacity utilization jointly explain changes in the manufactured exports.

\section{CONCLUSIONS AND RECOMMENDATIONS}

Having seen that there has been fluctuation in manufacturing export performance. Thus, there is need to overhaul the trade policies and evaluate them. Hence with stable exchange rate, it will help to curtail inflation, maintain a favorable balance of trade, boost export of domestic commodities and above all, maintains steady growth of the economy.

- It was found that exchange rate and trade openness determines the performance of manufactured exports in Nigeria and as such a more liberalization policy that is based on national interest objective through regional integration should be adopted and policies to discourage importation which normally put pressure on the demand for foreign exchange put in place.

- In addition, there is a bi directional relationship between manufactured export and capacity utilization and as such the Nigeria economy should be liberalize to attract foreign direct investment that will create opportunities for her large labor force thereby leading to the diversification of the economy from mono cultured status the country is currently experiencing.

\section{REFERENCES}

[1] A. Adenitikinju, African imperative in the new world trade order country case study of the manufacturing sector. Nigeria report present to the African economic research consortium (AERC), Nairobi, Kenya., 2002.

[2] Central Bank of Nigeria (CBN), Annual report and statement of accounts, various issues, 2012.

[3] Central Bank of Nigeria (CBN), Statistical bulletin, 2014.

[4] S. Olorunfemi, "Manufacturing performance in Nigeria; implication for sustainable development," Journal of Asian 
economic and financial review., vol. 12 , no. 2 , pp. 547-588, Mar. 2013.

[5] A. Adewuyi, "Trade policy reform and technical efficiency in Nigeria's Manufacturing sector," in Proceedings $7^{\text {th }}$ Annual African econometrics society (AEES) conference, 2006.

[6] M. Soderbom, F. Teal, "Are Manufacturing Exports the Key to Economic success in Africa," Journal of African Economies, vol. 12, no. 1, pp. 1-29, Dec. 2003.

[7] A. Adenikinju, S. Olofin, "Economic policy and manufacturing and sector growth performance in African," The Nigerian journal of economic and social studies, vol. 42, no. 1, pp. 1-22, Jun. 2000.

[8] M. Shameek, A Shahana, "Overview of India export performance trend and drivers," Indian Institute of Management working paper, 2014.

[9] J. Kankesu, "The impact of liberation on manufacturing sector performance in developing countries: A survey of the Literature," University of Wollongong, economics working papers, 2014.

[10] L. Afolabi, "Effect of trade liberalization on manufacturing sector performance in Nigeria," Journal of international development, vol. 3, no. 14, pp. 72-97, Aug. 2015.

[11]N. Rowbotham, A. Saville, D. Mbululu, "Exchange Rate Policy and Export Performance in Efficiency-Driven Economies," May, 2014.

[12] N. Toraganli, C. Yalcin, "Exports, Real Exchange Rates and External Exposures: Empirical Evidence from Turkish Manufacturing Firms," Working Papers 1624, Research and Monetary Policy Department, Central Bank of Turkey, 2016.

[13] M, Xinxin," The determinants of textile and apparel export performance in Asian Countries" M.S. thesis, Dept. Economics Iowa State University, 2013.

[14]H. W. Singer, H. Gray, "Trade policy and growth of developing countries: Some new data," World Development, vol. 16, pp. 395-403, 1988.

[15]R. Ahmed, "South Africa's exports performance: Any role for structural factors African department and strategy policy and review," 2016.

\section{Creative Commons Attribution License 4.0 (Attribution 4.0 International, CC BY 4.0)}

This article is published under the terms of the Creative Commons Attribution License 4.0

https://creativecommons.org/licenses/by/4.0/deed.en_US 